\title{
Beberapa catatan seputar TEKS DAN MELODI NYANYIAN JEMAAT
}

\author{
Branckly E. Picanussa
}

\begin{abstract}
Abstrak
Seiring dengan perkembangan ilmu pengetahuan dan teknologi, setiap hari selalu ada gubahan-gubahan baru untuk nyanyian jemaat dengan berbagai teks dan melodinya. Artikel ini hendak memberikan beberapa catatan seputar teks dan dan melodi nyanyian jemaat yang sebaiknya diperhatikan oleh para penggubah nyanyian jemaat.
\end{abstract}

Kata kunci: teks, melodi, nyanyian jemaat

\section{Pendahuluan}

Nyanyian jemaat adalah rangkaian teks (syair) yang tersusun sedemikian rupa dalam melodi sehingga dapat dinyanyikan secara bersamaan oleh orang-orang Kristen di dalam ibadah. Seiring dengan perkembangan ilmu pengetahuan dan juga musik, upaya untuk menggubah sebuah nyanyian juga mengalami perkembangan dari waktu ke waktu, tak terkecuali juga nyanyian jemaat. Nyanyian jemaat memiliki karakteristik teks dan melodi yang perlu diperhatikan oleh setiap penggubahnya, apakah para penggubah yang belajar secara akademik maupun para penggubah nyanyian jemaat yang belajar secara mandiri.

Artikel berikut ini memberikan beberapa informasi yang berhubungan dengan teks dan melodi nyanyian jemaat yang sebaiknya diperhatikan oleh setiap penggubah nyanyian jemaat sehingga nyanyian yang digubah dapat dinyaikan olah jemaat.

\section{Teks Nyanyian Jemaat}

Teks (syair, lirik) merupakan aspek yang pertama dan paling penting dari nyanyian jemaat. Pentingnya teks dalam nyanyian jemaat karena di dalamnya terdapat pesan yang dikomunikasikan. Teks dari nyanyian jemaat memiliki pesan iman kristiani tertentu. Bertemali dengan hal tersebut beberapa hal berikut ini perlu mendapat perhatian para penggubah nyanyian jemaat sehubungan dengan teks (syair): 
1. Teks (syair) dapat berasal dari Alkitab atau secara eksplisit merujuk pada bagian/ayat-ayat Alkitab (paraphrase) atau merupakan suatu refleksi terhadap suatu bagian Alkitab. Misalnya, teks Kidung Jemaat 4. HAI MARI SEMBAH, berdasarkan Mazmur 104;

1. Hai mari sembah Yang Mahabesar, nyanyikan syukur dengan bergemar. Perisai umatNya, Yang Mahaesa, mulia namaNya, takhtaNya megah!

2. Hai masyhurkanlah keagunganNya; cahaya terang itu jubahNya. Gemuruh suaraNya di awan kelam; berjalanlah Dia di badai kencang

3. Buana penuh mujizat ajaib, ya Khalik, Engkau membuatnya baik. Engkau memisahkan daratan dan laut dengan kuasa firman: besarlah Engkau!

4. PengasuhanMu betapa megah: udara dan t'rang menyatakannya, embun bertetesan dan hujan sejuk, lembah maupun bukit cermin kasihMu!

5. umatMu lemah dan dari debu, tetap memegang janjiMu teguh. Kasih setiaMu berlimpah terus, ya Khalik, Pembela dan Kawan kudus!

6. Ya Mahabesar, kekal kasihMu; malaikat memb'ri pujian merdu, pun kami, makhlukMu kecil dan lemah, mengangkat pujian serta menyembah.

Contoh yang lain, Kidung Jemaat 152. YESUS KATAKAN, “AKULAH”, berdasarkan Yohanes $14: 6$

1. Yesus katakan, "Akulah Jalan, Kebenaran, Hidup abadi dan kekal, Pohon kes'lamatan."

2. Akulah Jalan yang esa, yang menuju Bapa, Kub'ri hidupKu di salib menebus dunia.

3. Yesus, kusambut sabdaMu; t'rimalah pujian dan doa syukur dariku bagai persembahan

2. Teks dapat berasal dari atau merupkan refleksi teologis terhadap pengalaman, kenyataan, dan pengharapan hidup spiritual kristiani. Misalnya, Kidung Jemaat 371. AKU RINDU PADA YESUS

1. Aku rindu pada Yesus, Jurus'lamat dan Tuhanku; pada Dia 'ku mengaku dosa dan kesalahanku. Yesus b'rikanlah berkatMu.

2. Aku cinta pada Yesus yang mencariku selalu. Pada Dia 'ku mengaduh; waktu tersesat jalanku, Yesus pun memanggilaku

3. Aku ikut jalan Yesus; Dialah Terang bagiku. Yesus, t'rimalah hidupku; Yesus bimbinglah tanganku, jangan terlepas dariMu.

3. Teks dapat juga merupakan doktrin atau ajaran gereja.

4. Teks dapat dipahami oleh orang yang menyanyikannya

5. Teks terdiri atas sejumlah kesatuan matra (skema-skema pembagian aksen dalam kalimat), misalnya iambic $=\mathrm{V} /$; trochaic $=/ \mathrm{V} ;$ anapaestic $=/ \mathrm{V} \mathrm{V}$; dactylic $=\mathrm{V} \mathrm{V} \mathrm{/} \mathrm{).} \mathrm{Berikut} \mathrm{ini}$ beberapa contoh: 
Syair KJ. 358. SEMUA YANG LETIH LESU; Se/mu-a yang le/tih le-su, ber/do-sa, berce/la

Syair KJ. 365. TUHAN, AMBIL HIDUPKU; / Tu-han, am-bil/hi-dup-ku /dan ku-dus$\mathrm{kan} / \boldsymbol{b a}$-gi-Mu

6. Teks dapat juga berbentuk sajak (kesamaan bunyi dalam kata-kata syair, khususnya pada ujungujung baris, tetapi juga di tengah-tengah kalimat). Terdapat aneka ragam skema sajak yang ditandai dengan huruf a, b, c, d dan seterusnya. Salah satu contohnya adalah Kidung Jemaat. 169. MEMANDANG SALIB RAJAKU

Memandang salib Rajaku a yang mati untuk dunia $\quad b$ kurasa hancur congkakku a dan harta hilang harganya $b$

7. Teks memiliki metrik: S.M. (Short Meter: 66.86); S.M.D. (Short Meter Doubled: 86.88.D); C.M. (Common Meter: 86.86); C.M.D. (Common Meter Doubled: 86.86.D); L.M. (Long Meter: 88.88); L.M., with Refrain; L.M.D. (Long Meter Doubled: 88.88.D); Irregular, 77.77.77; 664.6664; dll. Berikut adalah beberapa contoh metrik dari nyanyian jemaat.

S.M. : KJ. 448. ALANGKAH INDAHNYA $\overbrace{\text { A-lang-kah in-dah-nya se-ri-kat ber-i-man }}$ cer-min-an ka-sih Tu-han-nya di da-lam sor-ga t'rang

S.M.D. : KJ. 226. DIA NOBATKANLAH

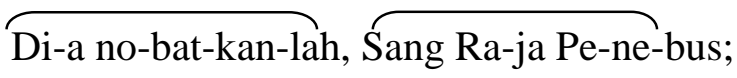

Ba-ha-na sor-ga ber-ge-ma me-muiji Di-a t'rus.

Hai bang-un, ji-wa-ku, ber-nya-nyi-lah ser-ta

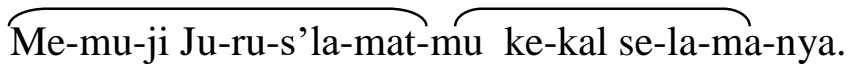

C.M. : KJ. 294. BERIBU LIDAH PATUTLAH

Be-ri-bu li-dah pa-tut-lâ me-mu-ji Tu-han-ku. Dan me-war-ta-kan kua-sa-Nya de-ngan ki-dung mer-du 
C.M.D. : KJ. 144. SUARA YESUS KUDENGAR

Su-a-ra Ye-sus ku-de-ngar, "Hai, ma-ri yang pe-nat,

se-rah-kan-lah ke-pa-da-Ku be-ban-mu yang be-rat."

Ke-pa-da Ye-sus, Tu-han-ku, 'ku da-tang ber-se-rah;

Ji-wa-ku yang le-tih-le-su di-bu-at-Nya le-ga.

L.M. : KJ. 27. MESKI TAK LAYAK DIRIKU

Mes-ki tak la-yak di-ri-ku, te-ta-pi kar'-na da-rah-Mu

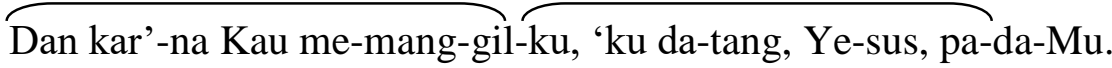

L.M., with Refrain: KJ. 410. TENANGLAH KINI HATIKU

Te-nang-lah ki-ni ha-ti-ku: Tu-han me-mim-pin lang-kăh-ku

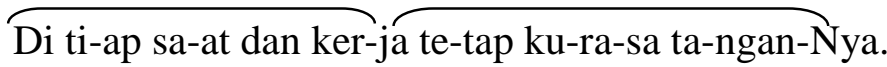

Refrein:

Irreguler: KJ. 92. MALAM KUDUS

Ma-lam ku-dus, su-nyi se-nyap; du-ni-a ter-le-lap.

Ha-nya du-a ber-ja-ga te-rus - a-yah bun-da mes-ra dan ku-dus;

A-nak ti-dur te-nang, A-nak ti-dur te-nang.

77.77.77. : KJ.37. BATU KARANG YANG TEGUH

Ba-tu ka-rang yang te-guh, Kau tem-pat-ku ber-te-duh

Kar'-na do-sa-ku be-rat dan kua-sa-nya me-nye-sak

oh, ber-sih-kan di-ri-ku o-leh da-rah lam-bung-Mu

664.6664 : KJ. 32. KULIHAT SALIBMU

Ku-li-hat sa-lib-Mu, ya Ju-ru-s'la-mât-ku, di Gol-go-ta. (664) 


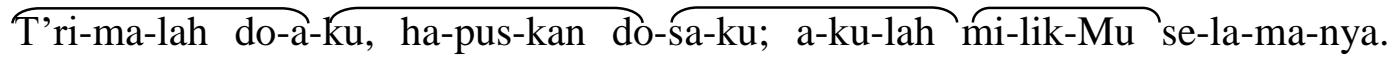
(6664)

8. Teks (syair) yang dibuat dapat juga dikembangkan dengan memerhatikan keanekaragaman bentuk nyanyian jemaat. Bentuk nyanyian jemaat yang paling asli adalah menyanyi berbalasan. Dialog nyanyian itu dapat dilakukan: antara satu orang - atau sekelompok kecil orang - penyanyi dan orang banyak (responsoris), antara dua kelompok penyanyi (antiphonal). Selain itu, ada juga nyanyian jemaat yang berbentuk Nyanyian Refrein. Nyanyian jemaat berbentuk refrein adalah nyanyian yang terdiri dari beberapa bait - sering disebut dengan ayat - dengan sebuah refrein. Nyanyian berbentuk refrein ini, dalam praktiknya, dapat juga dinyanyikan dengan mengombinasikan cara bernyanyi responsoris dan antiphonal dimana refrein dinyanyikan oleh seluruh pengibadah. Nyanyian berbentuk Strofe (Strophic/song: in stanzas each set to the same music). Nyanyian berbentuk strofe selain dinyanyikan seluruh baitnya oleh pengibadah, dapat juga dinyanyian secara alternatim (silih berganti) dari satu bait ke bait yang berikutnya oleh para pengibadah dalam kelompok-kelompok tertentu, misalnya jemaat pria dan wanita, orang tua dan anak-anak, paduan suara dan seluruh jemaat, jemaat dan musik pengiring yang dimainkan.

9. Unsur-unsur dari tata ibadah dapat juga dijadikan sebagai inspirasi untuk menyusun teks nyanyian jemaat:

1. Menghadap Allah:

○ nyanyian pembukaan yang mengekspresikan kesadaran jemaat yang sedang menghadap Tuhan

○ pengakuan dan pengampunan

○ doa permohonan

○ invokasi Roh Kudus

2. Firman Allah:

- Penciptaan

- Perjanjian Allah degan umat-Nya

○ Penantian Mesias

○ Kelahiran Yesus 
- Hidup dan Karya Yesus selaku Mesias

- Masa Pra-Paska

○ Sengsara dan Paska

- Hari Kenaikan dan Pentakosta

○ Roh Kudus dalam Jemaat

- Gereja di dunia dan di surge

- Akhir Zaman serta Kerajaan Kristus yang kekal.

3. Respons terhadap Firman Allah:

○ Pengucapan Syukur dan Puji-pujian

- Pengabdian dan Keesaan

- Pengakuan Iman dan Doa Syafaat - serta Doa Bapa Kami

- Sakramen dan Upacara Khusus Masa dan Musim

4. Penutup Ibadah

○ Pengutusan dan Berkat

5. Hidup Beriman Sehari-hari

6. Haleluya, Amin

\section{Melodi Nyanyian Jemaat}

Salah satu hal yang sangat penting dalam hubungan dengan melodi nyanyian jemaat adalah melodi yang tidak sulit dan melodi tersebut dapat dinyanyikan (singable) oleh banyak orang. Selain itu, interval dari melodi hendaknya dapat dijangkau oleh jemaat. Sehubungan dengan hal tersebut, perlu untuk dketahui bahwa wilayah nada yang dapat dinyanyikan dengan nyaman oleh banyak orang: terendah pada nada 6\# (li) atau 7b (ta/sa) dan nada tertinggi adalah 2\# (ri) atau 3b (ma). Dengan memerhatikan hal tersebut, seorang penggubah nyanyian jemaat akan dapat menghasilkan melodi yang nantinya dapat dinyanyikan dengan mudah oleh jemaat.

Hal yang tidak kalah penting adalah melodi nyanyian jemaat sebaiknya mendukung teks. Demikian juga ritme melodi sebaiknya memerhatikan juga ritme dari teks. Selain itu, melodi nyanyian jemaat dapat juga dikembangkan dengan memerhatikan keanekaragaman bentuk nyanyian jemaat, misalnya responsoris, antiphonal, refrain, strofe, alternatim, canon, 
Melodi nyanyian jemaat dapat ditata dengan menggunakan berbagai tangga nada. Berikut ini bebeberapa tangga nada yang dapat digunakan.

- Diatonis:

○ Mayor: 1234567

○ Minor: 6712345

- Pentatonis (lima nada)

○ Slendro: fa - sol - la - do - re

o Pelog: $\mathrm{mi}-\mathrm{fa}-\mathrm{sol}-(\mathrm{la})-\mathrm{ti}-\mathrm{do}-(\mathrm{re})-\mathrm{mi}$

- Sorog-Sunda / Selisir-Bali: la - ti - do $-($ re $)-$ me - fa $-($ sol $)-$ la

o Toraja: $\mathrm{ti}-\mathrm{do}-\mathrm{re}-(\mathrm{mi})-\mathrm{fa}-\mathrm{sol}-\mathrm{la}-\mathrm{ti}$

- Tetratonis (empat nada: $1-2-3-5 ; 1-3-5-6$; dll.)

- Tritonis (tiga nada: $6-1-2 ; 6-7-1$; dll.)

Berikut ini adalah salah satu contoh melodi nyanyian jemaat, KJ. 2. SUCI, SUCI, SUCI

\section{SUCI, SUCI, SUCI}

Reginald Heber 1826

do $=\mathrm{d} \quad 4$ ketuk
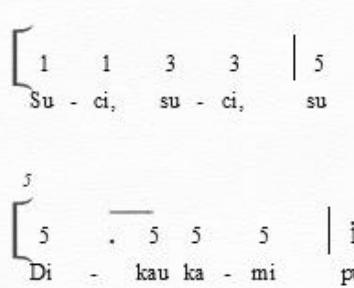

$\left[\begin{array}{rrrr}0 \\ 1 & 1 & 3 & 3\end{array} \mid\right.$

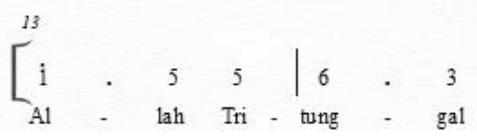

\section{Penutup}

Penggubahan nyanyian jemaat perlu memerhatikan teks dan melodi. Teks nyanyian jemaat dapat bersumber dari, antara lain Alkitab, ajaran gereja, dan refleksi iman kristiani. Teks nyanyian jemaat perlu mendapat dukungan dari melodi yang ditata dalam jangkauan nada-nada yang dapat 
dijangkau dengan baik oleh jemaat. Akhirnya, selamat menggubah nyanyian jemaat. TUHAN YESUS MEMBERKATI.

\section{Sumber-sumber:}

Hoffman Lawrence A., The Art of Public Prayer (Washington D.C.: The Pastoral Press, 1988)

Hymns for the Family of God (Nashville-Tennessee: Paragon Associates, Inc., 1976)

Lang Jovian P, Dictionary of the Liturgy (New York: Catholic Book Publishing Co., 1989)

Osbeck Kenneth W., 101 Hymns Stories: The Inspiring True Stories Behind 1001 Favorite Hymns

(Philippines: Back To The Bible, 2000)

Hymns (Philippines: Back To The Bible, 2000)

Pandopo H.A., Menggubah Nyanyian Jemaat (Jakarta: BPK Gunung Mulia, 1984)

Pattison Pat, Songwriting: Essential Guide to Lyric Form and Structure: Tools and Techniques for Writing Better Lyrics (Boston: Berklee Press, 1991)

Percy A. Scholes Percy A., The Concise Oxford Dictionary of Music (New York-Toronto: London Oxford University Press, 1964)

Perricone Jack, Melody in Songwriting: Tools and Technicues for Writing Hits Songs (Boston: Berklee Press, 2000)

Schilling S. Paul, The Faith We Sing (Philadelphia: The Westminster Press, 1983)

Sydnor James Rawlings, Hymns and Their Uses (Carol Stream-Illinois: AGAPE, 1982)

The Hymnal of the Protestant Episcopal Church in the United States of America (New York: The Church Pension Fund, 1960)

Webber Robert E., Ed., The Complete Library of Christian Worship: Volume 4 Music and the Arts in Christian Worship (Nashville-Tennessee: Star Song Publishing Group, t.t.)

Yamuger, Kidung Jemaat (Jakarta: Yamuger, 1985) 